\title{
Optimizing productive and reproductive performance in the grazing cow
}

\author{
Stephen T Butler, Sean B Cummins, Mary M Herlihy, Ian A Hutchinson and \\ Stephen G Moore \\ Teagasc, Animal and Grassland Research and Innovation Centre, Moorepark, Fermoy, \\ Co. Cork, Ireland
}

\begin{abstract}
The efficiency of milk production in pasture-based systems is heavily influenced by calving pattern, necessitating excellent reproductive performance in a short breeding season. Where grazed pasture is the major component of the diet, cows are underfed relative to their intake potential. A number of studies have identified body condition score measurements that are related to likelihood of both submission and conception. In general, fertility variables have favourable associations with circulating concentrations of glucose, insulin and insulin-like growth factor- 1 and unfavourable associations with non-esterified fatty acids, beta-hydroxybutyrate and endogenous growth hormone. Nutritional strategies to impact these metabolic indicators have been utilised, but effects on herd fertility are inconsistent. Long term selection for improved genetic merit for fertility traits increases the likelihood of pregnancy establishment. This is achieved through more favourable metabolic status, advancing postpartum resumption of cyclicity, improved postpartum uterine health, stronger behavioural oestrous expression and increased luteal phase circulating progesterone concentrations. Use of synchronisation to maximise submission rates can advance the timing of pregnancy establishment and improve calving pattern. Incorporation of sexed semen into the breeding programme can increase the number of female calves born, but at the expense of reduced conception rates. Nevertheless, careful selection of the heifers and cows to be inseminated with sexed semen will minimize the reduction in fertility performance. This review outlines the unique challenges of pasture-based systems, and the roles of nutritional management, genetic improvement of fertility traits, synchronisation and incorporation of sexed semen in the breeding programme in regulating reproductive performance.
\end{abstract}

\section{Introduction}

The objective of pasture-based milk production systems is to maximise the efficiency with which grazed grass is converted into milk (Dillon et al. 1995). Dairy production systems based

Corresponding author E-mail: stephen.butler@teagasc.ie 
on grazed pasture are primarily located in countries where environmental conditions support long growing seasons. Grass growth follows a seasonal profile; hence, the major challenge for reproductive management is to establish a calving pattern that matches the timing of peak herd feed demand with peak grass growth in late spring/early summer. Ideally, this involves a compact calving pattern in late winter/early spring, a compact breeding period in late spring/early summer, and all cows having a long lactation (mean 285 days) before dry-off in early to mid-winter. Poor fertility delays peak herd feed demand; the consequences of this include wasted pasture in early spring, inadequate pasture availability in late summer, increased concentrate supplementation, shorter average lactation length and a high proportion of cows with a long dry period (see Fig. 1).

The nutritional management of dairy cows in pasture-based systems is most heavily influenced by the stocking rate on the farm (McCarthy et al. 2011). As stocking rate increases, an individual cow is less likely to be able to reach her dry matter intake (DMI) potential, simply as a consequence
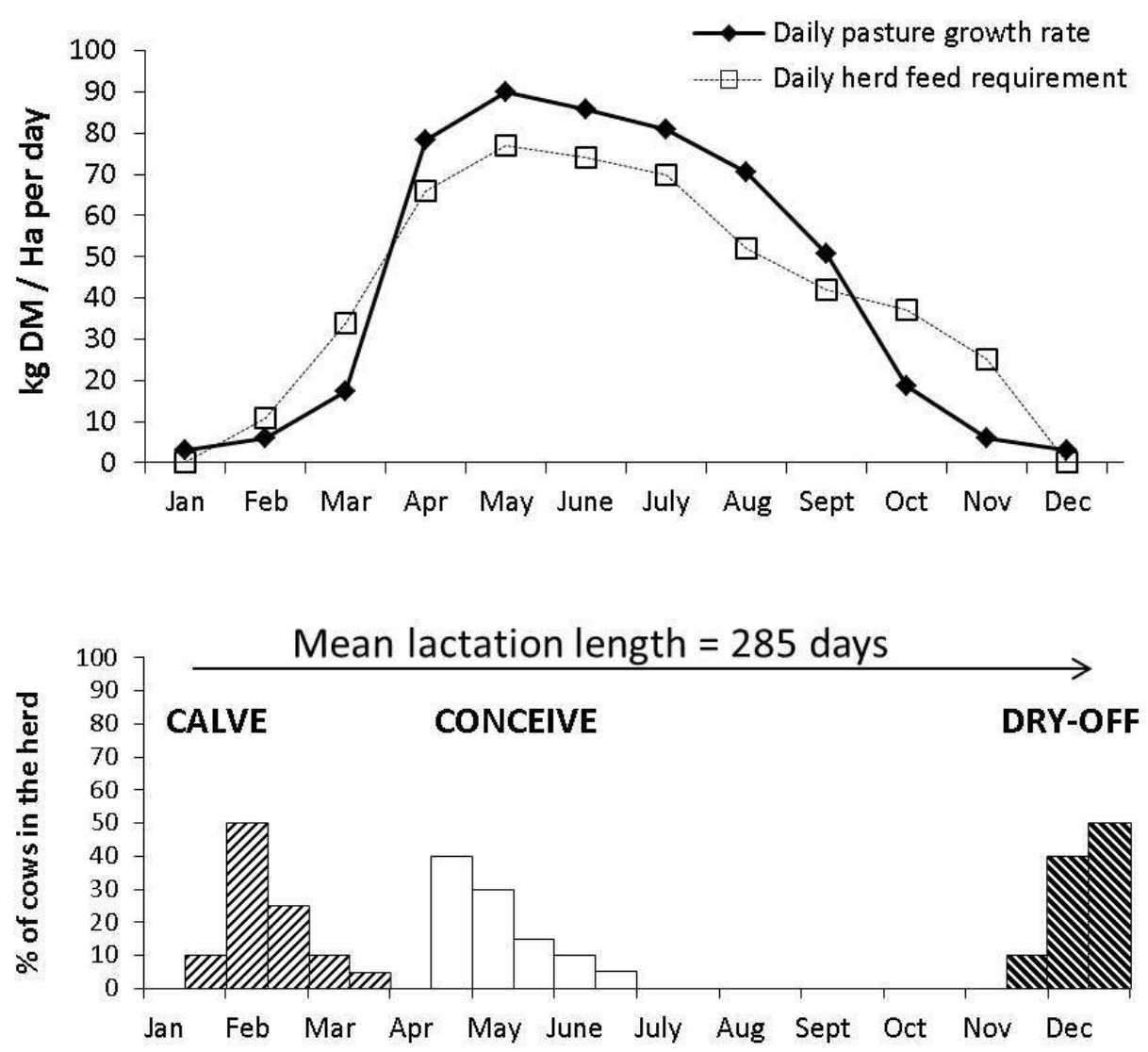

Fig. 1. Schematic representation of pasture-based seasonal-calving systems of milk production. Top panel: temporal patterns of pasture growth and herd feed demand. The objective is to match the timing of peak herd feed demand with peak pasture growth rates. Bottom panel: Seasonal pattern of calving, breeding and drying off. A compact calving pattern results in: (i) peak herd feed demand coinciding with peak pasture growth rate; (ii) most cows calved $\geq 42$ days at mating start date; (iii) rapid pregnancy establishment at the start of the breeding period; (iv) most cows having a long lactation on a primarily pasture-based diet; (v) most cows having a dry period of 8 to 10 weeks. Figure courtesy of B. Horan, Teagasc Moorepark and adapted from Holmes et al. (2002). Reprinted with permission from Butler (2014) $\odot$ The Animal Consortium 2014. 
of more cows trying to graze a finite amount of available grass. The cow responds by reducing milk yield, but the total milk produced on the farm increases because more cows are being milked. If the stocking rate is excessively high, cows are perpetually underfed and both productivity and fertility are reduced. If the stocking rate is excessively low, pasture is wasted and sward quality deteriorates (Dillon et al. 1995, Macdonald et al. 2008). The challenge is to identify the optimum stocking rate such that output of milk solids per hectare of land is maximised while individual cow fertility, health and welfare are not compromised. Body conditions score (BCS) is an objective assessment on an animal's available energy reserves, and a large body of evidence exists that underlines the relationship between BCS and reproductive success (Buckley et al. 2003, Roche et al. 2007). Nutritional management of the pasture-based cow largely revolves around managing BCS through the various phases of the reproductive calendar.

The advent of progeny testing and artificial insemination has markedly improved the production potential of dairy cows in all systems of production and transformed the dairy industry in many countries. Unfortunately, breeding objectives focussed solely on milk production for many years. This resulted in a major decline in genetic merit for fertility traits in most countries. In Scandinavia, however, fertility and health traits (most notably mastitis) have been incorporated into the breeding index for many years. While dairy cow fertility declined in most countries between 1985 and 2005, non-return rates, culling rates due to infertility and calving interval remained relatively constant in the Norwegian Red breed (Refsdal 2007). The incidence of veterinary treatments for reproductive disorders in 503,683 first-lactation daughters of 1,058 Norwegian Red sires was $3.1 \%$ for silent heats, $0.9 \%$ for metritis, $0.5 \%$ for cystic ovaries, and $1.5 \%$ for retained placenta (Heringstad 2010). The low incidence of fertility disorders and maintenance of high phenotypic fertility performance provide support for the objective of genetic selection for improved fertility. This review will examine the genetic, nutritional and management strategies that maximise the efficiency of pasture-based systems via improvements in reproductive performance.

\section{Fertility targets for seasonal calving systems}

A concentrated calving period necessitates excellent fertility in the preceding breeding season (Fig. 1). Fertility performance targets for the lactating herd in seasonal calving systems have been established (O'Farrell 1994, McDougall 2006, InCalf 2007). These targets are summarized in Table 1. Clearly, it is important that cows have a prompt resumption of cyclicity after calving, exhibit overt behavioural oestrus, and have a strong likelihood of establishing and maintaining pregnancy after insemination. Each of these variables is affected by nutritional status, genetics and herd reproductive management.

Table 1. Fertility targets in seasonal calving systems

\begin{tabular}{ll}
\hline $\begin{array}{l}\text { Cows calved by MSD } \\
\text { Cows resumed oestrous cyclicity by MSD }\end{array}$ & $100 \%$ \\
3 week submission rate ${ }^{2}$ & $\geq 70 \%$ \\
6 week pregnancy rate ${ }^{3}$ & $\geq 90 \%$ \\
12 week pregnancy rate ${ }^{4}$ & $\geq 70 \%$ \\
Breeding season duration $^{2}$ & $\geq 90 \%$ \\
\hline${ }^{1}$ Mating Start Date & $\leq 12$ weeks \\
$2 \%$ of cows bred during the first 3 weeks of the breeding season \\
$3 \%$ of cows that establish pregnancy during the first 6 weeks of the breeding season \\
$4 \%$ of cows that establish pregnancy during a 12 week breeding season
\end{tabular}


Energy Balance, BCS and metabolic indicators

It is generally accepted that energy balance (energy consumed minus energy required for maintenance and milk) is a key regulator of reproductive status (Butler \& Smith 1989, Chilliard et al. 2000). During early lactation, the energetic cost of milk production can exceed energy consumed, resulting in a prolonged period of negative energy balance (NEB) and consequent mobilization of body tissue reserves. A recent review noted that cows on pasture-based systems are generally thinner than cows on total mixed ration systems (Mee 2012), highlighting that the extent of body fat reserve depletion is likely to be greater. A study on two pasture-based herds in Florida reported that the incidence of elevated non-esterified fatty acid (NEFA) concentrations $(\geq 0.70 \mathrm{mM} / \mathrm{L}$ ) and subclinical ketosis ( $\beta$-hydroxybutyrate concentration (BHBA) $\geq 0.96 \mathrm{mM} / \mathrm{L}$ ) in blood samples collected from 771 cows during the early postpartum period was $20 \%$ and $35.4 \%$, respectively (Ribeiro et al. 2013). In a large survey of cow factors that affect fertility in spring-calving dairy cows in Ireland, both likelihood of submission for Al and likelihood of conception were positively related to nadir BCS, BCS during the breeding season, bodyweight gain during the breeding season and 305-d milk protein concentration (Buckley et al. 2003). In addition, it was also noted that 6 week in-calf rate was reduced when cows calved with a BCS $>3.0$ and subsequently lost >0.5 BCS units (Buckley et al. 2003). Similarly, the likelihood of pregnancy establishment at first service, following 6 weeks of breeding or following 12 weeks of breeding was positively associated with nadir BCS and negatively associated with postcalving BCS loss and bodyweight loss after the start of the breeding period (Roche et al. 2007). Calving at the appropriate BCS (3.00 to 3.25) and minimizing postpartum BCS loss ( $\leq 0.5$ BCS units) are associated with improved reproductive performance (Buckley et al. 2003, Roche et al. 2007, Ribeiro et al. 2013).

Several hormones (insulin, GH, leptin, glucocorticoids), growth factors (IGF1), and metabolites (glucose, NEFA, BHBA) have been identified that are stimulatory or inhibitory to the reproductive axis. In general, these factors tend to increase and decrease in tandem during unfavourable nutritional conditions (Butler et al. 2006). Reduced circulating concentrations of insulin, IGF-1, leptin, and glucose, and elevated concentrations of BHBA, NEFA, and glucocorticoids are all associated with impaired reproductive performance. The effects of and associations between - these different energy metabolites/metabolic hormones on the reproductive axis has recently been reviewed (Butler, 2014).

\section{Nutritional strategies to improve reproduction}

At first glance, it would appear that a simple strategy to favourably impact DMI, energy balance, BCS and metabolic indicators linked to reproduction would be to simply provide the grazing cow with additional dry matter via supplementation with high dry matter content concentrate feeds. On well managed pasture-based systems, however, simply supplementing cows with extra concentrate feed (composed of standard ingredients) does not improve fertility performance (Butler 2014). Instead, the additional energy ingested in the form of supplemental concentrate is partitioned to produce more milk. For example, Kennedy et al. (2002) reported that the mean milk yield response to additional concentrate in cows stocked at $2.47 \mathrm{cows} / \mathrm{ha}$ with high merit for milk production was 0.89 and $1.01 \mathrm{~kg}$ milk per kg concentrate DM as annual concentrate input increased from 376 to 810 and $1540 \mathrm{~kg} / \mathrm{cow}$, respectively. Corresponding values for cows with medium merit for milk production were 0.66 and $0.74 \mathrm{~kg}$ milk per $\mathrm{kg}$ concentrate DM, respectively. Similarly, Horan et al. (2005) evaluated the milk production response when annual concentrate input was increased from $364 \mathrm{~kg} / \mathrm{cow}$ to $1452 \mathrm{~kg} / \mathrm{cow}$ (both treatments stocked at 
$2.47 \mathrm{cows} / \mathrm{ha}$ ). The mean milk production response to increased concentrate supplementation in cows of North American ancestry was $1.08 \mathrm{~kg}$ of milk/kg of concentrate versus $0.43 \mathrm{~kg}$ or milk/kg concentrate for cows of New Zealand ancestry. Clearly, cows with high merit for milk production are genetically disposed towards increasing milk output in response to additional ingested nutrients. This was also noted by Cutullic et al. (2011); the milk production response to supplemental concentrate was greater in Holstein cows compared with Normande cows, despite Holstein cows having lower BCS. It can be inferred that when grazed grass is the main or only component of the diet, cows are underfed relative to their milk production potential. The degree that they are underfed is greater in cows with high merit for milk production than in cows with low merit for milk production. Genetic selection for increased milk production potential shifts the hierarchy of nutrient partitioning priorities towards increased milk production at the expense of BCS maintenance/repletion when additional concentrates are supplemented. While this improves day-to-day feed efficiency, it can reduce lifetime efficiency if reproductive failure is an outcome.

The focus of research on supplemental nutrition for pasture based systems in recent years has focussed on specific polyunsaturated fatty acid (PUFA) supplements (McNamara et al. 2003, Hutchinson et al. 2012a, Hutchinson et al. 2012b, Hutchinson et al. 2012c). Responses in terms of improved fertility performance have been small or non-existent. This is perhaps not surprising given that grazed grass is high in PUFA throughout the year (Butler 2014). Preliminary investigations have indicated that feeding a supplement composed primarily of non-structural carbohydrates (NSC) in the immediate postpartum period has beneficial implications for resumption of cyclicity and likelihood of pregnancy establishment in pasture-based systems (Burke et al. 2010). The improvement in fertility was associated with greater circulating glucose and IGF1. The effect of supplemental NSC feeding on phenotypic fertility needs to be tested in a large scale field trial.

\section{Influence of genetics on fertility}

During the latter part of the $20^{\text {th }}$ century, dairy cow breeding objectives in the majority of countries focussed solely on milk production. This inadvertently resulted in a major decline in genetic merit for fertility traits. The recent trends in breeding values for fertility traits and the physiological mechanisms affected by genetic merit for fertility traits have been reviewed (Butler 2013).

Angularity in the dairy cow is a subjective measure of adiposity. In addition to selecting for cows that produced more milk, greater angularity or sharpness was also considered favourable (i.e., cows also looked like they produced more milk). It has been well established that BCS is a key driver of cow health and fertility (Berry et al. 2003, Buckley et al. 2003, Lucy 2003, Weigel 2006, Roche et al. 2009, Cummins et al. 2012b, Moore et al. 2014). Favourable BCS, however, is the opposite of favourable angularity. It is likely that selecting for angularity directly contributed to the decline in phenotypic fertility and increased the incidence of metabolic disorders (Hansen 2000). Selecting for improved BCS has been identified as a strategy to improve health and fertility (Berry et al. 2003, Shook 2006, Weigel 2006).

In the US, productive life was incorporated into the index in 1994 and daughter pregnancy rate was added in 2003 (Cole et al. 2009). Currently, these two traits account for 33\% of the Net Merit index (22\% and $11 \%$, respectively). This halted roughly 40 years of a continuous decline in sire and dam breeding values for fertility (Weigel 2006). It has also been reported that the decline in phenotypic fertility performance has similarly been halted and started to improve (Norman et al. 2009). In 2003, the mean relative emphasis on production, durability, 
and health and reproduction traits across 15 countries was 59.5, 27.9, and $12.6 \%$, respectively (Miglior et al. 2005).

In Ireland, during the period from 1990 to 2001, genetic merit for milk yield increased by $25 \mathrm{~kg}$ per $\mathrm{yr}$, the proportion of Holstein genes increased from $8 \%$ to $63 \%$ and the calving rate to first service declined from $55 \%$ to $44 \%$ (Evans et al. 2006). High milk production North American Holstein cows were bred for a confinement based system, where energy dense Total Mixed Ration diets were the standard feeding practice. In a grass based system, the energetic demands associated with milk production could not be met solely by grass DMI, rendering the cows susceptible to excessive tissue mobilisation, negative energy balance, and reproductive failure (Buckley et al. 2000b, Horan et al. 2004). To address the problem of declining fertility, the Irish national breeding programme introduced a multi-trait selection index called the Economic Breeding Index (EBI) in 2001 (Veerkamp et al. 2002). This index included production and non-production traits, thus identifying animals of superior genetic merit for delivering onfarm profit. Each trait is given an economic weighting calculated using the Moorepark Dairy Systems Model (Shalloo et al. 2004). As the name 'Economic Breeding Index' suggests, the $\mathrm{EBI}$ is designed to identify genetically superior animals for profitability (Veerkamp et al. 2002). Currently, the EBI has 6 sub-indexes (relative emphasis in parenthesis); fertility/survival (35\%), milk production $(33 \%)$, calving performance $(10 \%)$, beef carcase $(9 \%)$, maintenance $(6 \%)$, management $(4 \%)$ and health (3\%) (http://www.icbf.com). The fertility sub-index is currently comprised of 2 traits; calving interval (24\%) and survival (11\%).

\section{Fert + and Fert- cows}

It is desirable to disentangle the effects of high merit for milk yield and poor merit for fertility traits. Cows with high genetic merit for milk production have generally been reported to have poorer fertility than cows with average genetic merit for milk production (Lucy \& Crooker 1999, Buckley et al. 2000a, Kennedy et al. 2003). It is unlikely, however, that high phenotypic milk production per se is directly responsible for poor fertility. Indeed, a number of studies have indicated similar or even superior fertility in high yielding cows compared to lower yielding cows (Nebel \& McGilliard 1993, Gröhn \& Rajala-Schultz 2000, Bello et al. 2013). As a result, it is difficult to identify specific mechanisms under genetic control responsible for poor fertility using animal models that differ in phenotypic milk production potential in addition to a wide range of associated phenotypes (milk composition, body weight, feed intake capacity, etc.).

To address this issue, a lactating cow model with similar genetic merit for milk production, but either good (Fert + ) or poor (Fert-) genetic merit for fertility traits was recently developed and validated (Cummins et al. 2012b). The two groups of cows were managed together under a standard pasture-based system operated in Ireland. This allowed the specific effects of genetic merit for fertility traits to be disentangled from the effects of genetic merit for milk production traits (similar in both genotypes) and environment (similar husbandry and general management). These animals have similar proportions of Holstein genetics, and similar body weight, milk yield and milk composition. Fertility performance, however, is markedly poorer in the Fertcows compared to the Fert + cows. The research conducted to date with this animal model has clearly demonstrated that the causes of reduced fertility in the Fert- cows are multifactorial (Butler 2013).

Physiological defects in Fert- cows that occur during the oestrous cycle include a longer oestrous cycle (25.1 vs. 21.0 days; $\mathrm{P}=0.01)$ and lesser circulating progesterone (P4) concentrations during the days 5 to 13 of the oestrous cycle $(3.84 \mathrm{vs} .5 .15 \mathrm{ng} / \mathrm{mL}$; $\mathrm{P}<0.001)$. 
A large volume of literature supports the pivotal role of P4 from day 5 to 13 of the oestrous cycle in influencing functional changes in histotroph composition (Green et al. 2005), structural changes in endometrial glandular duct density (Wang et al. 2007), endometrial gene expression (Forde et al. 2009), maternal recognition of pregnancy (Mann \& Lamming 2001) and likelihood of subsequent pregnancy establishment (Herlihy et al. 2013). Inherent differences in circulating P4 concentrations likely represent a key phenotype responsible for fertility differences in these two strains. In addition, the incidence of silent heats (defined as an ovulation event that was not preceded by oestrous behaviour) and the incidence of cows failing to ovulate after expressing oestrus were both increased in Fert- cows (Cummins et al. 2012a). Of the oestrus events recorded, $36 \%$ fell into the combined categories of silent heats and heats without ovulation in Fert- cows, whereas only $2 \%$ fell into the combined categories in Fert + cows. Interestingly, Cummins et al. (2012a) reported that mean circulating oestradiol (E2) concentrations during the period of pre-ovulatory follicle development were similar in both strains. In recent followup studies, however, we have observed greater circulating E2 concentrations on the day of oestrus in Fert + cows (Moore et al. 2014b). It is possible that sub-optimal P4 concentrations in the oestrous cycle pre-breeding interferes with the normal endocrine feedback mechanisms that are required to facilitate appropriately timed oestrous behaviour and ovulation.

Throughout lactation, circulating concentrations of IGF1 are greater in Fert + cows (Cummins et al. 2012b). Despite Fert + cows having greater circulating IGF1 concentrations, hepatic IGF1 gene expression was greater only in mid to late-lactation. The greater circulating IGF1 concentrations in early lactation appears to be mediated by reduced expression of low molecular weight binding proteins (Cummins et al. 2012c), allowing longer IGF1 half-life in the ternary complex (Jones \& Clemmons 1995). In addition to greater circulating IGF1 concentrations, Fert + cows have greater insulin and glucose concentrations during the immediate postpartum period (Cummins et al. 2012b, Moore et al. 2014). Elevated glucose concentrations in the immediate peripartum period has been linked to likelihood of early ovulation (Butler et al. 2006) and likelihood of conception at breeding (Garverick et al. 2013). Consistent with their superior metabolic status, Fert + cows maintained greater BCS during lactation and had reduced BCS loss after calving compared with Fert- cows (Cummins et al. 2012b, Moore et al. 2014). Maintenance of greater BCS in Fert + cows during early lactation is facilitated by greater DMI (Moore et al. 2014), and requires endocrine signalling to orchestrate appropriate partitioning of nutrients across multiple tissues and organs.

After parturition, the reproductive tract of all cows becomes exposed to microbial pathogens while the cervix remains open after delivery of the fetal-placental unit. The development of uterine disease depends on the type of bacteria involved and on the immune response of the cow, and is associated with reduced subsequent fertility (Sheldon et al. 2009). Clinical disease, lower DMI, increased presence of bacteria and greater NEFA and BHBA concentrations during the transition period have been associated with the incidence of endometritis between four and six weeks postpartum (LeBlanc 2012). We examined uterine health in Fert + and Fert- cows by assessing vaginal mucus scores weekly after calving and also by examining uterine cytology at three and six weeks postpartum (Moore et al. 2014). Vaginal mucus score was determined based on the criteria outlined by (Williams et al. 2005): (0) clear and translucent mucus; (1) mucus containing flecks of white or off-white pus; $(2)<50 \%$ white or off-white mucopurulent material.; or (3) $\geq 50 \%$ white or off-white mucopurulent material. Cows were classified as having endometritis if polymorphonuclear neutrophil (PMN) counts were greater than $18 \%$ and $10 \%$ in uterine cytology samples collected at weeks 3 and 6 postpartum, respectively (Sheldon et al. 2006). Both the vaginal mucus scores and uterine cytology results indicated greater incidence of endometritis in the Fert- cows. Despite similar management and housing, Fert + cows had a 
more rapid recovery in uterine health compared with Fert- cows. This likely indicates that the Fert + cows were capable of mounting a stronger and/or timelier immune response following exposure to microbial pathogens. Endometritis directly affects fertility through the altered local uterine environment, but also indirectly affects fertility through altered follicle development and function (Sheldon et al. 2002), delayed resumption of cyclicity (Galvão et al. 2010), altered follicle steroidogenesis (Green et al. 2011) and development of a smaller corpus luteum (CL) (Williams et al. 2007).

Collectively, the findings to date from the Fert + and Fert- animals underline that genetic progress for fertility traits is possible within the Holstein breed, and that this is possible without any detrimental effect on milk yield. With genomic selection now being routinely used in many countries, progress in identifying sires with good genetic merit for fertility traits will be much quicker than heretofore. The rate of genetic progress at herd level will be further accelerated through genotyping of all replacement heifers as calves, and only keeping those with high genomic proofs to enter the lactating cow herd. It is likely that this will become a common and routine practice within the next few years.

\section{Crossbreeding}

In New Zealand, cross-bred cows are now more prevalent than pure-breds, but cross-breeding continues to attract a minority interest in most other countries. The beneficial effects of crossbreeding arise from: (i) introduction of favourable genes from another breed that has been more intensively selected for traits of interest; (ii) removal of the inbreeding depression; and (iii) heterosis (Buckley et al. 2014). It is well established that cross-breeding results in hybrid vigour for both production traits (milk yield) and non-production traits (health, fertility). The fertility and survival gains that can be achieved in the F1 cross-bred are remarkable. Under a pasture-based system in Ireland, Prendiville et al. (2012) reported that the proportion of cows pregnant to first service $(+0.21 ; \mathrm{P}<0.01)$, in-calf after 6 weeks breeding $(+0.19 ; \mathrm{P}<0.05)$ and in-calf after 13 weeks breeding $(+0.08 ; \mathrm{P}<0.05)$ were greater for the Jersey $\times$ Holstein-Friesian compared with Holstein-Friesian and pure Jersey cows.

\section{Synchronisation}

In pasture-based systems, Al is generally carried out after spontaneous oestrus (observed or detected with heat detection aids), but targeted or whole-herd synchronisation (+/- timed Al) can be incorporated into the reproductive management to help maximise submission rates. The objective of synchronisation is to control both CL lifespan and the wave-like pattern of follicular growth to ensure that the onset of oestrus and the timing of ovulation are synchronised precisely, allowing a single timed artificial insemination (TAI) without the need for detection of behavioural oestrus (Macmillan 2010). An ideal protocol would result in synchronous ovulation of a dominant follicle with high fertility potential, irrespective of reproductive status or stage of the oestrous cycle at the onset of synchronisation. An injection of prostaglandin $\mathrm{F}_{2 \alpha}$ $\left(\mathrm{PGF}_{2 \alpha}\right.$ ) causes regression of a responsive $\mathrm{CL}$, whereby $\mathrm{P} 4$ concentrations decline rapidly to basal concentrations within 24 hours. This facilitates increased luteinizing hormone (LH) pulse frequency, causing an increase in E2 production by the dominant follicle, induction of an $\mathrm{LH}$ surge and ovulation (Diskin et al. 2002). Administration of exogenous gonadotropin-releasing hormone $(\mathrm{GnRH})$ also induces an LH surge, and has effects on ovarian follicle development that depend on follicular status at the time of administration. Follicles with a diameter $<10 \mathrm{~mm}$ 
have not acquired ovulatory capacity, whereas follicles $\geq 10 \mathrm{~mm}$ can ovulate in response to an $\mathrm{LH}$ surge induced by exogenous GnRH (Sartori et al. 2001). This results in both the formation of a CL and new follicle wave emergence within two to four days. Progesterone causes a potent suppression of oestrus and ovulation. Consequently, exogenous P4 in the form of intravaginal releasing devices is a powerful tool for the purposes of synchronising oestrus and ovulation in lactating dairy cows (Macmillan et al. 1991). Following P4 withdrawal at the end of a treatment period, the rapid drop in circulating P4 concentrations promotes a synchronous oestrus in treated cows, allowing for Al of large numbers of animals (Macmillan \& Peterson 1993).

The Ovsynch protocol combines use of $\mathrm{GnRH}$ and $\mathrm{PGF}_{2 \alpha}$ as follows: an injection of $\mathrm{GnRH}$, an injection of $\mathrm{PGF}_{2 \alpha}$ seven days later, a second injection of $\mathrm{GnRH} 56 \mathrm{~h}$ after the $\mathrm{PGF}_{2 \alpha}$ injection followed by TAI 16 to 20 hours later. In theory, the first GnRH causes an LH surge, ovulation of a dominant follicle and new wave emergence. The $\mathrm{PGF}_{2 \alpha}$ induces luteolysis 7 days later, and the second GnRH synchronises ovulation of the dominant follicle that arose from the new wave that emerged after the first GnRH (Pursley et al. 1995). Since the initial development of Ovsynch, strategies to increase the likelihood of conception after TAI have focussed on development of pre-synchronisation protocols to control the stage of the oestrous cycle when the Ovsynch protocol begins. These include: (i) Presynch-Ovsynch, which utilises two injections of PGF $_{2 \alpha}$ given 14 days apart 10 to 12 days before initiating Ovsynch (Moreira et al. 2001); (ii) Double-Ovsynch, which utilises one Ovsynch for presynchronisation followed 7 days later by a second Ovsynch for breeding (Souza et al. 2008); (iii) G6G, which utilises PGF ${ }_{2 \alpha}$ followed 2 d later by GnRH before initiating the Ovsynch protocol 6 days later (Bello et al. 2006). These protocols are all quite long; the duration of Presynch-Ovsynch, Double-Ovsynch, and G6G are 34,27 and 18 days, respectively, from the date of first injection to TAI. This is acceptable in confinement dairy systems with year-round calving. In seasonal-calving systems, long protocols are not practical for "late-calving" cows, but these are the cows that farmers are likely to be interested in synchronizing. Late calving cows (calved $<6$ weeks at mating start date) have greater likelihood of being anoestrous and lower likelihood of submission for insemination at the start of the breeding season compared with early calving cows.

The Ovsynch protocol has been evaluated in seasonal calving systems. Fertility results were satisfactory in cows that had a CL on the ovary, had calved $>80$ days, and were in BCS $>3.0$ at protocol initiation (Herlihy et al. 2011, Herlihy et al. 2013). However, these cows are also the least likely to require synchronisation. The Ovsynch protocol is not a suitable protocol for anoestrous cows as it results in low conception rates and high embryo mortality (Herlihy et al. 2013). Adding an intravaginal P4 releasing device to an Ovsynch protocol resulted in conception rates that were approximately similar to cows that were not treated, but advanced the timing of insemination and pregnancy establishment (McDougall 2010, Herlihy et al. 2011, Herlihy et al. 2013). Importantly, the duration of the protocol from start to finish is 10 days, making this a suitable protocol for pasture-based systems. Given that "normal" conception rates can be achieved with a P4-Ovsynch protocol, the calving pattern can be improved by maximising submission rate at the start of the breeding period. The impact on herd calving pattern will be greatest where existing heat detection efficiency is poor.

\section{Sexed semen}

Sexed semen is now widely available in dairy industries around the world (Seidel 2012). The process distinguishes $\mathrm{X}$ - and $\mathrm{Y}$-chromosome bearing sperm by measuring differences in fluorescence following staining the sperm with a non-toxic, DNA-binding dye (Hoechst 33342) (Johnson et al. 1987). Despite reliably producing approximately $90 \%$ gender bias, the fertility of the 
sexed semen product is compromised (Borchersen \& Peacock 2009, DeJarnette et al. 2009). The importance of reproductive performance is emphasised in seasonal production systems compared to year-round production systems, and is a key factor in determining profitability on pasturebased dairy farms (Veerkamp et al. 2002, Beukes et al. 2010). As a result, the uptake and usage of sexed semen to date has been limited in seasonal pasture-based systems. Nevertheless, sexed semen may have a role in seasonal calving systems (Butler et al. 2014). The potential advantages of incorporating sexed semen include greater heifer numbers at the start of the calving period, easier management of replacement heifers, more rapid herd expansion, improved biosecurity, elimination of low value male dairy calves and greater output of (higher value) beef crossbreed calves (Butler et al. 2014). In Europe, the dismantling of the EU milk quota regime in 2015 will allow farmers to expand herd size and milk output for the first time in a generation. Expansion will be quicker and more profitable if sexed semen is used compared with using conventional semen only (Hutchinson et al. 2013a, Hutchinson et al. 2013b). Availability of a sexed semen product with minimally impaired fertility would be extremely attractive to dairy farmers. Incremental improvements in the sorting technology will be developed over time, reducing the current gap in fertility performance between sexed semen and conventional semen. Data exists indicating that some bulls have little or no reduction in fertility after sorting (DeJarnette et al. 2010). Unfortunately, at this moment, there is no way to identify in advance sires that will maintain similar fertility after sorting. Is it possible to identify cows within a herd that are likely to have better likelihood of conception with sexed semen? Butler et al. (2014) reported that lactating cows that were both $\geq 63$ days postpartum and were in BCS $\geq 3.00$ had conception rates of $51 \%$ with sexed semen on a pasture based system. Clearly, sexed semen should be targeted at the higher fertility animals in a herd (i.e., early calving cows in good BCS). Successful integration of sexed semen into herd reproductive management to generate only the required number of heifers could effectively eliminate the unwanted (and low-value) male dairy calf, and completely change the economics of beef production from the dairy herd.

\section{Conclusions}

Fertility is the cornerstone of efficient pasture-based systems. Genetically selecting for improved fertility performance will yield dividends over time, but progress is slow. This progress can be accelerated through cross-breeding. Nutritional management should revolve around maintaining appropriate BCS at the various stages of the gestation-lactation cycle and ensuring that any deficiencies in the grazed pasture are compensated in the total diet (e.g., macro- or micro minerals). The key driver of calving pattern is submission rate. If this is unsatisfactory, targeted synchronisation should be adopted as a strategy to achieve maximum submission rates at the start of the breeding season. Sexed semen presents many potential advantages to the management of the seasonal calving dairy herd, but with reduced fertility performance, it's incorporation into breeding programme must be carefully considered and managed.

\section{Acknowledgements}

Funding through the Dairy Levy Trust, National Development Plan, the Teagasc Walsh Fellowship scheme, and the Department of Agriculture, Food and the Marine (RSF11/S/116 and RSF13/S/528) is gratefully acknowledged. 


\section{References}

Bello NM, Steibel JP, Erskine RJ \& Tempelman RJ 2013 Cows and herds constitute distinct hierarchical levels of heterogeneity in the variability of and association between milk yield and pregnancy outcome in dairy cows. Journal of Dairy Science 96 2314-2326.

Bello NM, Steibel JP \& Pursley JR 2006 Optimizing ovulation to first $\mathrm{GnRH}$ improved outcomes to each hormonal injection of ovsynch in lactating dairy cows. Journal of Dairy Science 89 3413-3424.

Berry DP, Buckley F, Dillon P, Evans RD, Rath M \& Veerkamp RF 2003 Genetic parameters for body condition score, body weight, milk yield, and fertility estimated using random regression models. Journal of Dairy Science 86 3704-3717.

Beukes PC, Burke CR, Levy G \& Tiddy RM 2010 Using a whole farm model to determine the impacts of mating management on the profitability of pasture-based dairy farms. Animal Reproduction Science 121 46-54.

Borchersen S \& Peacock M 2009 Danish A.I. field data with sexed semen. Theriogenology 71 59-63.

Buckley F, Dillon P, Crosse S, Flynn F \& Rath M 2000a The performance of Holstein Friesian dairy cows of high and medium genetic merit for milk production on grassbased feeding systems. Livestock Production Science 64 107-119.

Buckley F, Dillon P, Rath M \& Veerkamp RF 2000 b The relationship between genetic merit for yield and liveweight, condition score, and energy balance of spring calving Holstein Friesian dairy cows on grass based systems of milk production. Journal of Dairy Science 83 1878-1886.

Buckley F, Lopez-Villalobos N \& Heins BJ 2014 Crossbreeding - Implications for dairy cow fertility. Animal 8 Suppl S1 122-133.

Buckley F, O'Sullivan K, Mee JF, Evans RD \& Dillon P 2003 Relationships among milk yield, body condition, cow weight, and reproduction in spring-calved HolsteinFriesians. Journal of Dairy Science 86 2308-2319.

Burke CR, Kay JK, Phyn CVC, Meier S, Lee JM \& Roche JR 2010 Short communication: Effects of dietary nonstructural carbohydrates pre- and postpartum on reproduction of grazing dairy cows. Journal of Dairy Science 93 4292-4296.

Butler ST 2013 Genetic control of reproduction in dairy cows. Reproduction, Fertility and Development 26 1-11.

Butler ST 2014 Nutritional management to optimise fertility of dairy cows in pasture-based systems. Animal 8 Suppl S1 15-26.

Butler ST, Hutchinson IA, Cromie AR \& Shalloo L 2014 Applications and cost benefits of sexed semen in pasturebased dairy production systems. Animal 8 Suppl S1 165-172.

Butler ST, Pelton SH \& Butler WR 2006 Energy balance, metabolic status, and the first postpartum ovarian follicle wave in cows administered propylene glycol. Journal of Dairy Science 89 2938-2951.

Butler WR \& Smith RD 1989 Interrelationships between energy balance and postpartum reproductive function in dairy cattle. Journal of Dairy Science 72 767-783.
Chilliard Y, Ferlay A, Faulconnier Y, Bonnet M, Rouel J \& Bocquier F 2000 Adipose tissue metabolism and its role in adaptations to undernutrition in ruminants. Proceedings of the Nutrition Society 59 127-134.

Cole JB, VanRaden PM \& S-1040 M-SP 2009 AIPL Research Report NM\$4 (12-09): Net merit as a measure of lifetime profit: 2010 revision. http://aipl.arsusda.gov/reference/ nmcalc.htm\#Genetic Accessed 03/09/2013.

Cummins SB, Lonergan P, Evans AC \& Butler ST 2012a Genetic merit for fertility traits in Holstein cows: II. Ovarian follicular and corpus luteum dynamics, reproductive hormones, and estrus behavior. Journal of Dairy Science 95 3698-3710.

Cummins SB, Lonergan P, Evans ACO, Berry DP, Evans RD \& Butler ST 2012b Genetic merit for fertility traits in Holstein cows: I. Production characteristics and reproductive efficiency in a pasture-based system. Journal of Dairy Science 95 1310-1322.

Cummins SB, Waters SM, Evans AC, Lonergan P \& Butler ST 2012c Genetic merit for fertility traits in Holstein cows: III. Hepatic expression of somatotropic axis genes during pregnancy and lactation. Journal of Dairy Science 95 3711-3721.

Cutullic E, Delaby L, Gallard Y \& Disenhaus C 2011 Dairy cows' reproductive response to feeding level differs according to the reproductive stage and the breed. Animal 5 731-740.

DeJarnette JM, McCleary CR, Leach MA, Moreno JF, Nebel RL \& Marshall CE 2010 Effects of 2.1 and 3.5x10(6) sexsorted sperm dosages on conception rates of Holstein cows and heifers. Journal of Dairy Science 93 4079-4085.

DeJarnette JM, Nebel RL \& Marshall CE 2009 Evaluating the success of sex-sorted semen in US dairy herds from on farm records. Theriogenology 71 49-58.

Dillon P, Crosse S, Stakelum GK \& Flynn F 1995 The effect of calving date and stocking rate on the performance of spring-calving dairy cows. Grass and Forage Science $\mathbf{5 0}$ 286-299.

Diskin MG, Austin EJ \& Roche JF 2002 Exogenous hormonal manipulation of ovarian activity in cattle. Domestic Animal Endocrinology 23 211-228.

Evans RD, Dillon P, Berry DP, Wallace M, Ducrocq V \& Garrick DJ 2006 Trends in milk production, calving rate and survival of cows in 14 Irish dairy herds as a result of the introgression of Holstein-Friesian genes. Animal Science 82 423-433.

Forde N, Carter F, Fair T, Crowe MA, Evans AC, Spencer TE, Bazer FW, McBride R, Boland MP, O'Gaora P, Lonergan P \& Roche JF 2009 Progesterone-regulated changes in endometrial gene expression contribute to advanced conceptus development in cattle. Biology of Reproduction 81 784-794.

Galvão KN, Frajblat M, Butler WR, Brittin SB, Guard CL \& Gilbert RO 2010 Effect of early postpartum ovulation on fertility in dairy cows. Reproduction in Domestic Animals 45 e207-e211.

Garverick HA, Harris MN, Vogel-Bluel R, Sampson JD, Bader J, Lamberson WR, Spain JN, Lucy MC \& Youngquist RS 2013 Concentrations of nonesterified fatty 
acids and glucose in blood of periparturient dairy cows are indicative of pregnancy success at first insemination. Journal of Dairy Science 96 181-188.

Green MP, Hunter MG \& Mann GE 2005 Relationships between maternal hormone secretion and embryo development on day 5 of pregnancy in dairy cows. Animal Reproduction Science 88 179-189.

Green MP, Ledgard AM, Beaumont SE, Berg MC, McNatty KP, Peterson AJ \& Back PJ 2011 Long-term alteration of follicular steroid concentrations in relation to subclinical endometritis in postpartum dairy cows. Journal of Animal Science 89 3551-3560.

Gröhn YT \& Rajala-Schultz PJ 2000 Epidemiology of reproductive performance in dairy cows. Animal Reproduction Science 60-61 605-614.

Hansen LB 2000 Consequences of selection for milk yield from a geneticist's viewpoint. Journal of Dairy Science 83 1145-1150.

Heringstad B 2010 Genetic analysis of fertility-related diseases and disorders in Norwegian Red cows. Journal of Dairy Science 93 2751-2756.

Herlihy MM, Berry DP, Crowe MA, Diskin MG \& Butler ST 2011 Evaluation of protocols to synchronize estrus and ovulation in seasonal calving pasture-based dairy production systems. Journal of Dairy Science 94 44884501.

Herlihy MM, Crowe MA, Berry DP, Diskin MG \& Butler ST 2013 Factors associated with fertility outcomes in cows treated with protocols to synchronize estrus and ovulation in seasonal-calving, pasture-based dairy production systems. Journal of Dairy Science 96 1485-1498.

Holmes CW, Wilson GF, Mackenzie DDS, Flux DS, Brookes IM \& Davey AWF 2002 Milk production from pasture, 3rd edition. Wellington, New Zealand: Butterworths of New Zealand.

Horan B, Dillon P, Faverdin P, Delaby L, Buckley F \& Rath M 2005 The interaction of strain of Holstein-Friesian cows and pasture-based feed systems on milk yield, body weight, and body condition score. Journal of Dairy Science 88 1231-1243.

Horan B, Mee JF, Rath M, O'Connor P \& Dillon P 2004 The effect of strain of Holstein-Friesian cow and feeding system on reproductive performance in seasonal-calving milk production systems. Animal Science 79 453-467.

Hutchinson IA, Dewhurst RJ, Evans AC, Lonergan P \& Butler ST 2012a Effect of grass dry matter intake and fat supplementation on progesterone metabolism in lactating dairy cows. Theriogenology 78 878-886.

Hutchinson IA, Hennessy AA, Dewhurst RJ, Evans ACO, Lonergan P \& Butler ST 2012b The effect of strategic supplementation with trans-10,cis-12 conjugated linoleic acid on the milk production, estrous cycle characteristics, and reproductive performance of lactating dairy cattle. Journal of Dairy Science 95 2442-2451.

Hutchinson IA, Hennessy AA, Waters SM, Dewhurst RJ, Evans AC, Lonergan P \& Butler ST 2012c Effect of supplementation with different fat sources on the mechanisms involved in reproductive performance in lactating dairy cattle. Theriogenology 78 12-27.

Hutchinson IA, Shalloo L \& Butler ST 2013a Expanding the dairy herd in pasture-based systems: The role for sexed semen use on virgin heifers. Journal of Dairy Science 96 1312-1322.

Hutchinson IA, Shalloo L \& Butler ST 2013b Expanding the dairy herd in pasture-based systems: The role of sexed semen use in virgin heifers and lactating cows. Journal of Dairy Science 96 6742-6752.

InCalf 2007 http://www.incalf.com.au. Accessed 22/03/2014.

Johnson LA, Flook JP, Look MV \& Pinkel D 1987 Flow sorting of $X$ and $Y$ chromosome-bearing spermatozoa into two populations. Gamete Research 16 1-9.

Jones JI \& Clemmons DR 1995 Insulin-like growth factors and their binding proteins: biological actions. Endocrine Reviews 16 3-34.

Kennedy J, Dillon P, Faverdin P, Delaby L, Buckley F \& Rath M 2002 The influence of cow genetic merit for milk production on response to level of concentrate supplementation in a grass-based system. Animal Science 75 433-445.

Kennedy J, Dillon P, O'Sullivan K, Buckley F \& Rath M 2003 The effect of genetic merit for milk production and concentrate feeding level on the reproductive performance of Holstein-Friesian cows in a grass-based system. Animal Science 76 297-308.

LeBlanc SJ 2012 Interactions of Metabolism, Inflammation, and Reproductive Tract Health in the Postpartum Period in Dairy Cattle. Reproduction in Domestic Animals 47 18-30.

Lucy MC 2003 Mechanisms linking nutrition and reproduction in postpartum cows. Reproduction Supplement 61 415-427.

Lucy MC \& Crooker BA. 1999. Physiological and genetic differences between low and high index dairy cows. In Fertility in the high producing dairy cow. Occasional publication no. 26 - British Society of Animal Science, pp. 223-236.

Macdonald KA, Penno JW, Lancaster JA \& Roche JR 2008 Effect of stocking rate on pasture production, milk production, and reproduction of dairy cows in pasturebased systems. Journal of Dairy Science 91 2151-2163.

Macmillan KL 2010 Recent advances in the synchronization of estrus and ovulation in dairy cows. The Journal of Reproduction and Development 56 Suppl S42-47.

Macmillan KL \& Peterson AJ 1993 A new intravaginal progesterone releasing device for cattle (CIDR-B) for oestrous synchronisation, increasing pregnancy rates and the treatment of post-partum anoestrus. Animal Reproduction Science 33 1-25.

Macmillan KL, Taufa VK, Barnes DR \& Day AM 1991 Plasma progesterone concentrations in heifers and cows treated with a new intravaginal device. Animal Reproduction Science 26 25-40.

Mann GE \& Lamming GE 2001 Relationship between maternal endocrine environment, early embryo development and inhibition of the luteolytic mechanism in cows. Reproduction 121 175-180.

McCarthy B, Delaby L, Pierce K, Journot F \& Horan B 2011 Meta-analysis of the impact of stocking rate on the productivity of pasture-based milk production systems. Animal 5 784-794. 
McDougall S 2006 Reproduction performance and management of dairy cattle. Journal of Reproduction and Development 52 185-194.

McDougall S 2010 Effects of treatment of anestrous dairy cows with gonadotropin-releasing hormone, prostaglandin, and progesterone. Journal of Dairy Science 93 1944-1959.

McNamara S, Butler T, Ryan DP, Mee JF, Dillon P, O'Mara FP, Butler ST, Anglesey D, Rath M \& Murphy JJ 2003 Effect of offering rumen-protected fat supplements on fertility and performance in spring-calving HolsteinFriesian cows. Animal Reproduction Science 79 45-56.

Mee JF 2012 Reproductive issues arising from different management systems in the dairy industry. Reproduction in Domestic Animals 47 42-50.

Miglior F, Muir BL \& Van Doormaal BJ 2005 Selection indices in Holstein cattle of various countries. Journal of Dairy Science 88 1255-1263.

Moore SG, Fair T, Lonergan P \& Butler ST 2014a Genetic merit for fertility traits in Holstein cows: IV. Transition period, uterine health, and resumption of cyclicity. Journal of Dairy Science 97 2740-2752.

Moore SG, Scully S, Browne JA, Fair T \& Butler ST 2014b Genetic merit for fertility traits in Holstein cows: V. Factors affecting circulating progesterone concentration. Journal of Dairy Science http://dx.doi.org/10.3168/ jds.2014-8133.

Moreira F, Orlandi C, Risco CA, Mattos R, Lopes F \& Thatcher WW 2001 Effects of presynchronization and bovine somatotropin on pregnancy rates to a timed artificial insemination protocol in lactating dairy cows. Journal of Dairy Science 84 1646-1659.

Nebel RL \& McGilliard ML 1993 Interactions of high milk yield and reproductive performance in dairy cows. Journal of Dairy Science 76 3257-3268.

Norman HD, Wright JR, Hubbard SM, Miller RH \& Hutchison JL 2009 Reproductive status of Holstein and Jersey cows in the United States. Journal of Dairy Science 92 3517-3528.

O'Farrell KJ. 1994. Measurement of fertility in seasonallycalving dairy herds. In R\&H Hall Technical Bulletin, Dublin, Ireland 2, pp. 1-8.

Prendiville R, Shalloo L, Pierce KM \& Buckley F 2012 Comparative performance and economic appraisal of Holstein-Friesian, Jersey and Jersey x Holstein-Friesian cows under seasonal pasture-based management. Irish Journal of Agricultural and Food Research 50 123-140.

Pursley JR, Mee MO \& Wiltbank MC 1995 Synchronization of ovulation in dairy cows using $\mathrm{PGF}_{2 \alpha}$ and $\mathrm{GnRH}$. Theriogenology 44 915-923.

Refsdal A 2007 Reproductive performance of Norwegian cattle from 1985 to 2005: trends and seasonality. Acta Veterinaria Scandinavica 495.

Ribeiro ES, Lima FS, Greco LF, Bisinotto RS, Monteiro APA, Favoreto M, Ayres H, Marsola RS, Martinez N, Thatcher WW \& Santos JEP 2013 Prevalence of periparturient diseases and effects on fertility of seasonally calving grazing dairy cows supplemented with concentrates. Journal of Dairy Science 96 5682-5697.
Roche JR, Friggens NC, Kay JK, Fisher MW, Stafford KJ \& Berry DP 2009 Invited review: Body condition score and its association with dairy cow productivity, health, and welfare. Journal of Dairy Science 92 5769-5801.

Roche JR, Macdonald KA, Burke CR, Lee JM \& Berry DP 2007 Associations among Body Condition Score, body weight, and reproductive performance in seasonal-calving dairy cattle. Journal of Dairy Science 90 376-391.

Sartori R, Fricke PM, Ferreira JC, Ginther OJ \& Wiltbank MC 2001 Follicular deviation and acquisition of ovulatory capacity in bovine follicles. Biology of Reproduction $\mathbf{6 5}$ 1403-1409.

Seidel GE, Jr. 2012 Sexing mammalian sperm - Where do we go from here? The Journal of Reproduction and Development 58 505-509.

Shalloo L, Dillon P, Rath M \& Wallace M 2004 Description and validation of the Moorepark Dairy System Model. Journal of Dairy Science 87 1945-1959.

Sheldon IM, Cronin J, Goetze L, Donofrio G \& Schuberth HJ 2009 Defining postpartum uterine disease and the mechanisms of infection and immunity in the female reproductive tract in cattle. Biology of Reproduction $\mathbf{8 1}$ 1025-1032.

Sheldon IM, Lewis GS, LeBlanc S \& Gilbert RO 2006 Defining postpartum uterine disease in cattle. Theriogenology 65 1516-1530.

Sheldon IM, Noakes DE, Rycroft AN, Pfeiffer DU \& Dobson H 2002 Influence of uterine bacterial contamination after parturition on ovarian dominant follicle selection and follicle growth and function in cattle. Reproduction 123 837-845.

Shook GE 2006 Major Advances in Determining Appropriate Selection Goals. Journal of Dairy Science 89 1349-1361.

Souza AH, Ayres H, Ferreira RM \& Wiltbank MC 2008 A new presynchronization system (Double-Ovsynch) increases fertility at first postpartum timed $\mathrm{Al}$ in lactating dairy cows. Theriogenology 70 208-215.

Veerkamp RF, Dillon P, Kelly E, Cromie AR \& Groen AF 2002 Dairy cattle breeding objectives combining yield, survival and calving interval for pasture-based systems in Ireland under different milk quota scenarios. Livestock Production Science 76 137-151.

Wang CK, Robinson RS, Flint APF \& Mann GE 2007 Quantitative analysis of changes in endometrial gland morphology during the bovine oestrous cycle and their association with progesterone levels. Reproduction 134 365-371.

Weigel KA 2006 Prospects for improving reproductive performance through genetic selection. Animal Reproduction Science 96 323-330.

Williams EJ, Fischer DP, Noakes DE, England GCW, Rycroft A, Dobson H \& Sheldon IM 2007 The relationship between uterine pathogen growth density and ovarian function in the postpartum dairy cow. Theriogenology 68 549-559.

Williams EJ, Fischer DP, Pfeiffer DU, England GCW, Noakes DE, Dobson H \& Sheldon IM 2005 Clinical evaluation of postpartum vaginal mucus reflects uterine bacterial infection and the immune response in cattle. Theriogenology 63 102-117. 
